\title{
Petrol Fiyatları ve Borsa Endeks Değeri Arasındaki İlişki : Ortadoğu Ülkeleri Örneği
}

\author{
DOI: $10.26466 /$ opus.598831
}

\author{
$*$

\section{Erkan Alsu*} \\ *Dr. Öğr. Üyesi, Gaziantep Üniversitesi, İktisadi ve İdari Bilimler Fakültesi, Gaziantep/Türkiye \\ E-Posta: alsu@gantep.edu.tr \\ ORCID: $\underline{0000-0001-6102-1786}$
}

Öz

Bu çalışmanın amacı petrol fiyatları ile borsa endeks değerleri arasında uzun dönem ve kısa dönem nedensellik ilişkisinin incelenmesidir. Bu kapsamda ham petrol fiyatlarn ile Türkiye, Suudi Arabistan, Ürdün, Birleşik Arap Emirlikleri, Bahreyn, Katar ve Kuveyt gibi Ortadoğu ülkelerinin borsa endekslerine ait veriler kullanulmıştır. Bu çalışmada, Nisan 2004 ile Mart 2019 yılları arasındaki döneme ilişkin aylık fiyat verileri ele alınmıştır. Bu çalışmada, Ortadoğu ülkelerinin seçilmiş olması bu ülkelerin dünya petrol üretiminin yaklaşık üçte birini üretmiş olmasıdır. Çalışmada, nedensellik ilişkisinin ortaya konulması amacıyla, Hatemi J ve Maki eşbütünleşme testleri ve sonrasında ise Toda-Yamamoto ve Fourier Toda Yamamoto nedensellik testleri yardım ile analiz edilmiştir. Çalışmanın sonucunda Suudi Arabistan dı̧̧ındaki diğer ülkelerin endekslerinin uzun dönemde petrol fiyatlarn ile eşbütünleşik ilişkiye sahip olduklar ve kısa dönemde petrol fiyatlarından $B A E$, Bahreyn, Katar ve Kuveyt endekslerine doğru bir nedensellik ilişkisinin var olduğu tespit edilmiştir. Ayrıca, kısa dönemde BAE ve Kuveyt ülkelerine ait borsa endekslerden, petrol fiyatlarnna doğru bir nedensellik ilişkisinin olduğu belirlenmiştir.

Anahtar Kelimeler: Petrol fiyatları, Borsa Endeks Değeri, Hatemi J, Maki Eşbütünleşme 


\title{
Relationship Between Oil Prices And Stock Market Index Value: A Case Of Middle East Countries
}

\begin{abstract}
The aim of this study is to investigate the long-term and short-term causality relationship between oil prices and stock market index values. In this context, crude oil prices with Turkey, Saudi Arabia, Jordan, United Arab Emirates, Bahrain, the data belonging to Middle Eastern countries such as Qatar and Kuwait stock exchange index is used. In this study, monthly price data for the period between April 2004 and March 2019 are discussed. In this study, The reason why the Middle Eastern countries were selected is that these countries produced about one third of the world's oil production. These data were analyzed with the help of Hatemi J and Maki cointegration tests and then Toda-Yamamoto and Fourier Toda Yamamoto causality tests in order to reveal the causality relationship. As a result of this study, it was found that the indices of the countries other than Saudi Arabia have a cointegrated relationship with the oil prices in the long run and there is a causal relationship from the oil prices to the UAE, Bahrain, Qatar and Kuwait indices in the short run. In addition, it is determined that there is a causality relationship from the stock market indexes of UAE and Kuwait countries to oil prices in the short term.
\end{abstract}

Keywords: $\quad$ Oil prices, Stock Market Index Value, Hatemi J, Maki Cointegration 


\section{Giriş}

Petrol fiyatlarının makroekonomik değişkenler üzerindeki etkisi, literatürde oldukça sık tartışılan ve araştırılan bir konu olarak görülmektedir. Petrol fiyatlarındaki dalgalanmaların küresel ekonomi üzerine etkileri 1970'li yıllardan itibaren akademik literatürde sıklıkla çalışılan ve dikkat çeken önemli konuların başında gelmektedir. Bu doğrultuda yapılan çalışmalar incelendiğinde, 1980 'lerden itibaren petrol fiyatlarındaki değişimin enflasyon, büyüme, işsizlik, cari açık vb. gibi ekonomik faaliyetler üzerindeki rolünü araştıran birçok çalışma ile karşılaşılmaktadır (Kilian ve Park 2008; Olufisayo 2014; Güngör ve diğ. 2016; Alagöz ve diğ. 2017). Özellikle gelişmekte olan ülkelerin enerji ihtiyaçlarının büyük bir bölümünün petrol ve yan ürünlerinden elde edilmesi nedeni ile petrol fiyatlarındaki dalgalanmalar, bu ülkelerin temel ekonomik göstergeleri üzerinde çeşitli etkiler meydana getirmektedir.

Ortadoğu ülkelerinde yaşanan jeopolitik riskler sonucu petrol arzında yaşanacak bir daralma , petrol fiyatlarında artışa neden olmaktadır. Petrol fiyatında yaşanan artışlar, diğer dünya ülkelerinin ekonomik göstergeleri üzerinde etkiler meydana getirmektedir. Zira petrol, tüketim ve yatırım mallarının üretiminde yoğun olarak kullanılan temel bir ürün olarak kabul edilmektedir. Üretim faaliyetleri genel olarak petrole veya yan ürünlerine dayanmaktadır. Bundan dolayı da petrol günümüzde küresel ekonominin vazgeçilmez bir unsuru haline gelmiş ve küreselleşen dünyanın işleyişi için kritik öneme sahip olmuştur. Diğer taraftan, petrol fiyatlarındaki artış, işletmelerin üretim maliyetlerini artırmakta ve bundan dolayı da işletmelerin karlılığı üzerinde olumsuz bir etki meydana getirmektedir. İşetmelerin maliyetlerindeki bu artışlar ekonomide uzun vadede enflasyonist bir etki meydana getirmektedir. Petrol fiyatlarındaki artışların işletmelerin maliyetlerini artırması sonucu oluşan enflasyon, işletmelerin reel kazançlarında değişimler meydana getirmektedir. İşletmenin mali durumunda meydana gelen bu değişimler işletmelerin pay senedi fiyatlarını da etkilemektedir. Dolayısı ile petrol fiyatlarındaki bu değişimlerin etkisi ülkelerin pay senedi piyasalarında görülmekte ve dalgalanmalara neden olmaktadır. Bu bağlamda, dünya ekonomisinde petrolün temel enerji kaynağı olduğu, sanayi ve teknolojinin özünü oluşturduğu göz 
önüne alındığında küreselleşen piyasalarda petrol fiyatlarındaki değişimlerin tüm dünya ekonomisine yön verdiği görülmektedir.

Ortadoğu coğrafyası petrolün arzının oldukça fazla olduğu bir coğrafya olarak bilinmektedir. Bu coğrafya da birçok ülke ekonomisi için petrol üretimi hayati önem taşımaktadır. Yıllara göre ham petrol üretimi incelendiğinde, 2017 yılında Dünya petrol üretimi içerisinde Orta Doğu ülkelerinin petrol üretiminin, \% 34,1 ile en yüksek paya sahip olduğu tespit edilmiştir. İkinci sırayı ise \%21,7 ile Kuzey Amerika almaktadır. 2017 y1lında dünya ham petrol tüketimi incelendiğinde ilk sıranın Asya-Pasifik bölgesinde olduğu, son sıranın ise Afrika'ya ait olduğu tespit edilmiştir (BP, 2019).

Bu çalışmanın, var olan literatüre iki farklı şekilde katkı sağlaması beklenmektedir. Bu çalışmanın var olan literatüre ilk olarak şu şekilde katkı sağlaması beklenmektedir. Petrol üreten ülkelerin bulunduğu coğrafya küresel tehditlerin ve risklerin olduğu, önemli terör saldırılarının yaşandığı bir coğrafya olarak bilinmektedir. Bu kapsamda bu bölgede yapisal kırılmaların sık yaşandığı görülmektedir. Petrol fiyatlarının, bu yapısal k1rılmalardan dolayı aşırı dalgalanması yapılan analizlerde yapısal kırılmaların dikkate alınmaması durumunda hatalı istatistiksel sonuçların elde edilmesine neden olmaktadır. Bu çalışmada hem 2 yapısal kırılmaya hem de 5 yapısal kırılmaya kadar izin veren Hatemi J ve Maki eşbütünleşme testleri kullanılmıştır. Bu kapsamda çalışma bizim bildiğimiz kadarıyla, literatürde yapısal kırılmaları dikkate alarak yapılan ilk çalışma olarak görülmektedir. Bu çalışmanın var olan literatüre ikinci olarak şu şekilde katkı sağlayacağı düşünülmektedir. Bu çalışmada dünya petrol üretiminin yoğun olduğu Ortadoğu ülkeleri ve bu ülkelerden yoğun bir şekilde petrol ithal eden Türkiye birlikte analiz edilmiştir. Bizim bildiğimiz kadarıyla literatürde Ortadoğu ülkeleri ile ilgili yapılmış herhangi bir çalışma bulunmamaktadır. Halbuki yıllara göre ham petrol üretimi incelendiğinde, 2017 yılında Dünya petrol üretimi içerisinde Orta Doğu ülkelerinin petrol üretiminin, \% 34,1 ile en yüksek paya sahip olduğu tespit edilmiştir. Petrol üretiminin bu ülkelerde fazla olması, bu ülkelerin gelir düzeylerinin de oldukça yüksek olmasına neden olmaktadır. Bu ülkelerde petrolden elde edilen gelirlerin finansal piyasalara aktarılması küresel finansal kaynak arzı açısından önem arz etmektedir. Petrol fiyatları ile borsa endeks değeri arasındaki nedensellik ilişkisinin ve yönünün ortaya 
çıkarılması küresel ekonomik politikalar açısından da oldukça fazla önem arz etmektedir. Bu kapsamda, bu çalışmanın literatürde var olan bu boşluğu doldurması düşünülmektedir.

$\mathrm{Bu}$ çalışmada petrol fiyatları ile borsa endeks değerleri arasındaki ilişkinin test edilmesi amaçlanmıştır. Bu kapsamda, 2004 Nisan ve 2019 Mart tarihleri arasındaki dönem ele alınmış ve bu döneme ilişkin aylık veriler kullanılmıştır. Çalışmada petrolün, ekonomileri üzerinde hayati öneme sahip olduğu düşünülen; Suudi Arabistan, Birleşik Arap Emirlikleri (BAE), Katar, Kuveyt, Bahreyn, Ürdün gibi bazı orta doğu ülkeleri ve bu ülkeler ile çeşitli kültürel ve ekonomik ilişkilere sahip olan, bunun yanı sıra gelişmekte olan sanayisi ve ekonomisi açısından bir petrol ithalatçısı ülke konumunda olan Türkiye gibi ülkeler ele alınmış ve bu ülkelere ait endeks fiyatları ile petrol fiyatları arasındaki nedensellik ilişkisi incelenmiştir. Bu kapsamda, öncelikle ülke endekslerinin petrol fiyatları ile uzun dönemde birlikte hareket edip etmediği Hatemi J ve Maki eşbütünlşeme testleri yardımı ile test edilmiş, ardından ise nedensellik ilişkisinin incelenebilmesi için Toda-Yamamoto ve Fourier Toda Yamamoto gibi nedensellik testlerinden yararlanılmış elde edilen bulgular yorumlanmıştır.

\section{Literatür Taraması}

Her ne kadar petrol fiyatlarındaki değişimler ve borsa endeks değerindeki değişimleri anlamak için önemli bir faktör olarak kabul edilse de, petrol fiyatları ile borsa endeks değeri arasındaki ilişki konusunda kesin bir fikir birliği bulunmamaktadır. Farklı çalışmalardan elde edilen sonuçların çeşitliliği, birçok araştırmacının, petrol fiyatları ve borsa endeks değeri arasındaki ilişkiyi analiz etmeye daha fazla teşvik etmektedir. Bu kapsamda literatürde tespit edilen çalışmalardan bir kısmına aşağıda yer verilmektedir.

Kaul ve Seyhun (1990) ve Sadorsky (1999) 1970'lerde ve 1980'lerde petrol fiyatlarındaki oynaklığın ABD hisse senedi fiyatları üzerinde olumsuz bir etki gösterdiğini savunmuşlardır. Papapetrou (2001), 1990'ların sonlarında Yunanistan için geliştirilen bir çalışmada, petrol fiyatlarındaki şokların, üretim ve istihdam artışın olumsuz yönde etkilediği için hisse senetlerinin olumsuz etkilendiği sonucuna ulaşmıştır. Hong vd., (2002) ise ABD'de gerçekleştirdikleri bir çalışmada, petrol fiyatları ile borsa getirileri 
arasında negatif bir ilişkinin olduğunu belirlemişlerdir. Aynı şekilde, O’Neil vd., (2008) ve Park ve Ratti (2008) yaptıkları çalışmalarda petrol fiyatlarındaki artışın, gelişmiş on üç piyasada hisse senedi fiyatları üzerinde istatistiksel olarak önemli bir olumsuz etkiye sahip olduğu sonucuna ulaşmışlardır.

Basher ve Sadorsky (2006), petrol fiyat riskinin gelişmekte olan borsalar üzerindeki etkisini analiz etmişlerdir. Araştırmada, petrol fiyatlarının, petrol üreticisi olmayan şirketlerin maliyet yapısını etkileyerek hisse senedi fiyatlarını etkilediğine dikkat çekmişlerdir. Bulgular, maliyet yapısındaki böyle bir değişikliğin tüketicilere tam olarak yansıtılamayacağı ve bu nedenle de kar ve temettünün azaltılmasıyla hisse senedi fiyatları üzerinde şok etkisi oluşturulabileceğini göstermektedir. Benzer bir yaklaşımla, Chung-Rou ve Shih-Yi (2014), petrol fiyat şoklarının Çin, Hindistan ve Rusya gibi gelişmekte olan ekonomilerin hisse senedi fiyatları üzerindeki etkisini incelemişlerdir. Petrol fiyatlarındaki şokun, gelişmekte olan ekonomilerin üçünde de hisse senedi getirilerini etkilediği sonucuna ulaşmışlardır.

Boyer ve Filion (2007) tarafından yapılan araştırmada, Kanada enerji stoklarının genel piyasaların getirileriyle ve ham petrol ve doğal gaz fiyatlarının değerlenmesiyle pozitif ilişkili olduğu bulunmuştur. Miller ve Ratti'nin (2009) yaptığı çalışmada dünya petrol fiyatları ile uluslararası borsalar arasındaki ilişkiye bakmıştır. Analizin sonucunda, borsa endekslerinin uzun vadede petrol fiyatlarındaki artışlara ters yönde bir tepki verdiği tespit edilmiştir. Ancak yazarlara göre, bu kalıp 2000 yılı başından itibaren parçalanmaya başlamıştır.

Hammoudeh, Dibooglu ve Aleisa (2004) tarafindan yapılan çalışma, Suudi hisse senedi getirileri ve petrol fiyatlarındaki değişimler arasında çift yönlü bir ilişki olduğunu göstermiştir. Bhar ve Nikolova (2010), küresel petrol fiyatı getirilerinin Rusya hisse senedi getirileri ve oynaklığı üzerinde önemli bir etkisi olduğunu tespit etmiştir. Buna karşılık, Huang, Masulis ve Stoll (1996) çalışmalarında, petrol fiyatları ile hisse senedi getirileri arasında anlamlı bir ilişki bulamadıklarını belirterek, petrol vadeli işlem getirilerinin ABD borsa getirileri ile ilişkili olmadığını ifade etmiştir.

Hasan ve Mahbobi (2013) tarafından petrol fiyatlarının Kanada borsaları üzerindeki etkisi üzerine yapılan araştırma, petrol fiyatlarının Kanada borsaları üzerindeki etkisinin ikinci dönemde güçlü şekilde arttığını 
göstermiştir. Güler ve Nalın (2013) tarafından yapılan çalışmada, 20002009 yılları verileri ile Türkiye kapsamındaki çalışmasında model olarak Engle Granger eş bütünleşme testi yöntemi ile çalışılmıştır. Çalışma sonucunda petrol fiyatı üzerinden hisse senedi fiyatına yönelik tek yönlü nedensellik ilişkisi saptanmaktadır. Kapusuzoğlu ve İbicioğlu (2013) çalışmalarında, 2000-2010 yılı verilerini esas alarak Johansen eş bütünleşme ve Vektör hata düzeltme yöntemini uygulamış olup, hisse senedinden petrol fiyatına doğru tek yönlü nedensellik olduğu sonucunu tespit etmişlerdir. Abdioğlu ve Değirmenci (2014) 2005-2013 yılları arası günlük veri setini kullanarak Borsa İstanbul (BİST) kapsamındaki çalışmalarında, hisse senedi fiyatları üzerinden petrol fiyatlarına doğru bir nedensellik ilişkisi olduğu sonucunu elde etmişlerdir.

Wei ve Guo (2017), petrol fiyat şokları ile Çin borsaları arasındaki ilişkiyi analiz etmişlerdir. Çalışma neticesinde, pay senedi getirilerinin petrol şoklarına verdiği tepkilerin farklı olduğunu ve bunun petrol fiyatlarındaki değişikliklerin sebepleriyle büyük ölçüde ilişkili olduğunu belirtmişler ve pay senetlerindeki oynaklığın petrol şoklarına verdiği tepkilerin oldukça düşük olduğunu belirlemişlerdir.

\section{Metodoloji}

Bu çalışmada, Suudi Arabistan, Birleşik Arap Emirlikleri (BAE), Katar, Kuveyt, Bahreyn, Ürdün gibi bazı orta doğu ülkeleri ve Türkiye'ye ait borsa endeks değeri ile petrol fiyatları arasında bir nedensellik ilişkisinin olup olmadığ incelenmektedir. Bu kapsamda, 2004 Nisan ve 2019 Mart tarihleri arasındaki dönem ele alınmış ve bu döneme ilişkin petrol fiyatı ve ülke endekslerine ait aylık veriler kullanılmıştır. Bu veriler, Finnet, investing.com ve Yahoo finans gibi çeşitli veri paylaşım platformlarından elde edilmiştir.

Çalışmada, nedensellik ilişkisinin incelenmesi amacıyla Toda-Yamamoto ve Fourier Toda Yamamoto nedensellik testlerinden faydalanılmıştır. Ancak daha öncesinde serilere ait durağanlık düzeylerinin incelenebilmesi için çeşitli birim kök testleri kullanılmış ardından ise ülke endekslerinin uzun dönemde petrol fiyatları ile birlikte hareket edip etmediğinin belirlenmesi adına, iki kırılmayı dikkate alana Hatemi j ve beş kırılmaya kadar müsaade eden Maki eşbütünleşme testleri kullanılmıştır. Bunun 
ardından ise nedensellik testlerine geçilmektedir. Bahsi geçen bu testlere ilişkin metodolojilere aşağıda yer verilmektedir.

Çalışmada öncelikle serilerin durağanlığının incelenebilmesi için literatürde sıklıkla kullanılan ve yapısal kırılmaları dikkate almayan Augmented Dickey-Fuller (ADF) ve Phillips - Perron (PP) gibi birim kök testleri ile birlikte yapısal kırılma tarihinin içsel olarak belirlendiği Zivot Andrews, tek kırılmalı birim kök testi kullanılmıştır.

Zivot Andrews birim kök testi kapsamında, Sıfır hipotezinde serinin yapısal değişim olmaksızın entegre olduğu düşünüldüğü için, alternatif hipotezde serinin bilinmeyen kırılma zamanı ile bir trend durağan süreç tarafından temsil edildiği varsayılmaktadır.

Çalışmada ayrıca ülke endeks fiyatlarının petrol fiyatları ile uzun dönemde birlikte hareket edip etmediği incelemektedir. Bu kapsamda iki k1rılmyı dikkate alan Hatemi J (2008) ve beş kırılmaya kadar izin veren Maki (2012) eşbütünleşme testlerinden faydalanılmıştır. Hatemi-J 2008 yılındaki çalışmasıyla, Gregory ve Hansen (1996) tarafından geliştirilen tek ve tek yapısal kırılmanın varlığına izin veren eşbütünleşme testini genişleterek, iki yapısal kırılmanın varlığına izin veren eşbütünleşme testini geliştirmiştir. Hatemi-J gerçekleştirmiş olduğu bu çalışmada hem sabitte hem de eğimde olmak üzere iki yapısal kırılmanın etkisini aşağıda belirtilen denklemi dikkate alarak ifade etmeye çalışmıştır. Verilen bu denklemde içsel olarak iki yapısal kırılmaya izin verilmektedir (Hatemi-J, 2008).

$$
y_{t}=\alpha_{0}+\sum_{i=1}^{2}\left(\alpha_{i} D_{i t}+\beta_{i}^{\prime} D_{i t} x_{t}\right)+\beta_{0}^{\prime} x_{t}+u_{t}
$$

Burada $\alpha_{0}$ yapısal kırılma öncesindeki sabit terimi ifade ederken , $\alpha_{1}$ ilk yapısal kırılma nedeniyle, $\alpha_{2}$ ise ikinci yapısal kırılma nedeniyle sabit terimde oluşan değişimi ifade etmektedir. $\beta_{0}$ yapısal kırılma öncesindeki eğim parametresini ifade ederken, ilk yapısal kırılmanın eğimde neden olduğu etkiyi $\beta_{1}$, ikinci yapısal kırılmanın neden olduğu etkiyi ise $\beta_{2}$ parametresi ifade etmektedir.

$\tau_{1} \in(0,1)$ ve $\tau_{2} \in(0,1)$ ilgili yapısal değişim noktasının zamanlamasını belirten bilinmeyen parametreleri göstermekte iken yapısal kırılmaların etkilerini modele taşıyan gölge değişkenler ise şu şekilde ifade edilmektedir: 


$$
\mathrm{D}_{1 t}=\left\{\begin{array}{l}
1 \rightarrow t>\left[n \tau_{1}\right] \\
0 \rightarrow t \leq\left[n \tau_{1}\right]
\end{array}\right\}
$$

$$
\mathrm{D}_{2 t}=\left\{\begin{array}{l}
1 \rightarrow t>\left[n \tau_{2}\right] \\
0 \rightarrow t \leq\left[n \tau_{2}\right]
\end{array}\right\}
$$

Değişkenler arasında eşbütünleşme ilişkisinin olmadığını gösteren hipotezin test edilmesi için $\mathrm{ADF}^{*}, Z_{\alpha}$ ve $Z_{\mathrm{t}}$ istatistikleri kullanılmaktadır. $\mathrm{ADF}^{*}$ istatistiği elde edilen kalıntılara ADF birim kök test istatistiği uygulanması sonucunda elde edilirken, $Z_{\alpha}$ test istatistiği $Z_{\alpha}=n\left(\hat{\rho}^{*}-1\right)$ şeklinde hesaplanmaktadır (Hatemi-J, 2008).

Maki (2012) eşbütünleşme testi, seriler arasında eşbütünleşme ilişkisini test ederken, beş yapısal kırılma kadar izin vermektedir. Ayrıca yapısal kırılma tarihlerini de vermektedir. Yapısal kırılmaların 3 veya daha fazla olması durumunda bu yöntemin, Gregory ve Hansen (1996) ve Hatemi-j (2008) yöntemlerden daha üstün olduğu ifade edilmektedir (Maki, 2012). Maki(2012) testinin yapılabilmesi için tüm serilerin serilerin I(1) düzeydinde durağan olması gerekmektedir.

Maki (2012) testi dört farklı model üzerine geliştirilmiştir.

Model 0: Sabit terimde kırılma var, trendsiz model.

$$
\begin{aligned}
& \stackrel{y_{t}}{=\mu} \\
& +\sum_{i=1}^{k} \mu_{i} K_{i, t}+\beta x_{t} \\
& +u_{t}
\end{aligned}
$$

Model 1: Sabit terimde ve eğimde kırılma var, trendsiz model. 


$$
\begin{gathered}
y_{t}=\mu+\sum_{i=1}^{k} \mu_{i} K_{i, t}+\beta x_{t} \\
+\sum_{i=1}^{k} \beta_{i} x_{i} K_{i, t} \\
+u_{t}
\end{gathered}
$$

Model 2: Sabit terimde ve eğimde kırılma var, trendli model.

$$
\begin{array}{r}
y_{t}=\mu+\sum_{i=1}^{k} \mu_{i} K_{i, t}+\gamma x+\beta x_{t} \\
+\sum_{i=1}^{k} \beta_{i} x_{i} K_{i, t}+u_{t}
\end{array}
$$

Model 3: Sabit terimde, eğimde ve trendde kırılma var.

$$
\begin{gathered}
y_{t}=\mu+\sum_{i=1}^{k} \mu_{i} K_{i, t}+\gamma t+\sum_{i=1}^{k} \gamma_{i} t K_{i, t}+\beta x_{t} \\
+\sum_{i=1}^{k} \beta_{i} x_{i} K_{i, t}+u_{t}
\end{gathered}
$$

$K_{i}$, kukla değişkenleri ifade etmektedir. Maki (2012) şöyle tanımlanmıştır: $K_{i}= \begin{cases}1 & \mathrm{t}>\mathrm{T}_{\mathrm{B}} \text { iken } \\ 0 & \text { diğer durumlarda }\end{cases}$

Burada Тв yapısal kırılma tarihini göstermektedir. Testin temel hipotezi " $H_{0}$ : Yapısal kırılmalar altında eşbütünleşme yoktur" şeklinde ifade edilmektedir. Testin kritik değerleri, Monte Carlo simülasyonu yardımı ile hesaplanmış ve Maki (2012)' de ifade edilmiştir. Hesaplanan değer, kritik değerden küçük olduğunda, $H_{0}$ reddedilmekte ve seriler arasında eşbütünleşme ilişkisinin var olduğu ifade edilmektedir.

Son olarak, petrol fiyatları ile belirlenen ülkelerin borsa endeks verileri arasında herhangi bir nedensellik ilişkisinin var olup olmadığının test edilebilmesi için Granger (1969) çalışmasından yola çıkan ve Granger nedensellik testinin birer uzantısı olan Toda - Yamamoto ve Fourier Todo - Yamamoto gibi iki farklı nedensellik testinden faydalanılmıştır. Ancak bu iki yönteme geçmeden önce kısaca Granger nedensellik testinden bahsetmek yararlı olacaktır. Granger nedensellik testine ilişkin temel model aşağ1da birinci denklemde verilmektedir. 


$$
y_{t}=\alpha+\beta_{1} y_{t^{-1}+\cdots+\beta_{p}} y_{t^{-p}}+\varepsilon_{t}
$$

Burada $y_{t}$ çok değişkenli tahminlerde tüm değişkenleri içeren $\mathrm{K}$ endojen değişkenlerden oluşmaktadır, $\alpha$ kesişme terimlerinin bir vektörünü, $\beta$ katsayı matrislerini ve son olarak $\varepsilon_{t}$ ise beyaz gürültü kalıntılarını ifade etmektedir. Geleneksel Granger nedensellik testleri, sıkıntı parametrelerinin gerekliliği gibi bazı zorluklara sahiptir. Ayrıca, değişkenler entegre veya eşbütünleşik ise test istatistiği geçerli olmayacak ve kendi dağılımını takip etmeyecektir (Toda ve Yamamoto, 1995).

Toda ve Yamamoto (1995), serinin maksimum entegrasyon (dmax) s1rasına göre belirlenen ekstra gecikmeli $(k)$ VAR $(p)$ modelini ortaya atmıştır. Toda ve Yamamoto, nedensellik testi, Granger nedenselliğini incelemek için, düzeltilmiş VAR modelinin tahminine dayalı bir yöntemdir. Toda ve Yamamoto (1995) testinin klasik nedensellik testlerinden temel farkı ve avantajı serilerin aynı seviyede durağan olması zorunluluğunu ortadan kaldırmasıdır. TY yaklaşımı, değişkenlerin düzeylerine göre $V A R$ $(p+d)$ modelini tahmin etmekte ve asimptotik olarak ki-kare dağılımını izlemektedir (Çiftçi, 2018).

TY Yöntemin de ilk aşama, VAR modelinde uygun gecikme düzeyinin (p) belirlenmesidir. İkinci aşamada, p gecikmeye, en yüksek entegrasyona sahip değişkenin entegrasyon düzeyinin (dmax) ilave edilmesi, üçüncü aşamada, $\mathrm{p}+\mathrm{dmax}$ gecikme için serilerin orijinal değerleri üzerine EKK modelinin tahmin edilmesi ve son aşamada ise, değişkenler için sırasıyla kısıtlama konulması ve kısıtlamaların anlamlılı̆̆ının sınanması gibi işlemler gerçekleşmektedir. Toda ve Yamamoto (1995)'in ortaya atmış olduğu VAR $(p+d)$ modeli aşağıda yer alan ikinci denklemde verilmektedir.

$$
y_{t}=\alpha+\beta_{1} y_{t^{-1}+\cdots+\beta_{p^{+}}} y_{t-(p+\mathrm{d})}+\varepsilon_{t}
$$

Görüldüğü üzere TY modeli birinci denklemde verilen klasik Granger modeline entegresyon düzeyinin (dmax)'ın eklenmiş halinden ibarettir. TY modelinde $y t$, yapısal kırılmaları öngörmemektedir. Ancak, VentosaSantaulària ve Vera-Valdés (2008) tarafından gerçekleştirilen Monte Carlo simülasyonları, veri üretme sürecinde yapısal kaymaların olabildiğini ve bazen iki değişkenin arasında herhangi bir nedensel bağın 
bulunmamasına rağmen H0: nedensellik bulunmamaktadır hipotezinin reddedilebileceğini ortaya koymuştur. Bu durumu, Enders ve Jones (2015)'in Monte Carlo simülasyonlarını kullanarak gerçekleştirmiş oldukları çalışma sonucunda elde ettikleri benzer bir bulgular da desteklemektedir.

Elde edilen bu bulgular, Granger nedensellik analizinin, yapısal kırılmalar göz ardı edildiğinde veya yanlış olarak dikkate alındığında yanıltıcı sonuçlar verebildiğini, yapısal değişimlerin hesaba alınması gerektiğini, hatta yapısal değişimlerin nasıl ele alındığının da önemli olduğunu göstermektedir.

Bu nedenle, çalışma kapsamında yapısal kırılmaları dikkate almayan Todo-Yamamoto nedensellik testinin yanı sıra Enders ve Jones (2016)'nın ortaya koyduğu yapısal kırılmalarında dikkate alındığı VAR çerçevesinde Fourier yaklaşımının bir uzantısı olan Nazlioglu, Görmüs ve Soytas (2016) tarafından geliştirilmiş olan kademeli yapısal kırılmaların dikkate alındığı Fourier Todo-Yamamoto nedensellik testi kullanılmıştır. Bu yaklaşıma ait model ise aşağıda verilmektedir.

$$
y_{t}=\alpha(\mathrm{t})+\beta_{1} y_{t^{-1}+\cdots+\beta_{p^{+d}}} y_{t-(p+d)}+\varepsilon_{t}
$$

Kesişme terimleri $\alpha(\mathrm{t})$ 'nin zamana bağımlı olduğu ve $y_{t}$ ' deki yapısal değişimleri gösterdiğini ifade etmektedir. Yapısal değişimleri, bilinmeyen bir tarih, sayı ve kırılma biçimiyle aşamalı bir süreç olarak ele almak için ise Fourier yaklaşımı aşağıdaki gibi tanımlanmaktadır:

$$
\alpha(\mathrm{t}) \cong \alpha_{0}+\sum_{k=1}^{n} \gamma_{1 k} \sin \left(\frac{2 \mathrm{nkt}}{\mathrm{T}}\right)+\sum_{k=1}^{n} \gamma_{2 k} \operatorname{Cos}\left(\frac{2 \mathrm{nkt}}{\mathrm{T}}\right)
$$

Denklem (4)'de n, frekansların sayısını ve $k$ ise bir tamsayı frekansını temsil etmektedir. Denklem (4) 'ün denklem (3)' e eklenmesiyle birlikte ortaya denklem (5) çıkmaktadır. Oluşturulan bu yeni denklem ise aşağıdaki gibidir:

$$
\begin{aligned}
& y t=\alpha_{0}+\sum_{k=1}^{n} \gamma_{1 k} \sin \left(\frac{2 \mathrm{nkt}}{\mathrm{T}}\right)+\sum_{k=1}^{n} \quad \gamma_{2 k} \operatorname{Cos}\left(\frac{2 \mathrm{nkt}}{\mathrm{T}}\right)+\beta_{1} y_{t-1}+\ldots \ldots+\beta_{p^{+} d} \\
& y_{t^{-}\left(p^{+} d\right)+\varepsilon_{t}}
\end{aligned}
$$


Bu çalışma da Fourier frekansı ve gecikme uzunluklarının sayısını belirlemek için Akaike bilgi kriteri kullanılmış ve bu kritere göre en uygun $k$ ve $p$ değerleri seçilmiştir. Ayrıca çalışmada, Wald istatistiğinin frekans sayısına bağlı olabileceği ve bundan dolayı asimptotik ki-kare dağılımını takip etmeyebileceğinden ötürü, Wald test istatistiğinin Bootstrap dağ1lımı kullanılmıştır.

\section{Bulgular}

Çalışma kapsamında petrol fiyatları ile ele alınan ülkelerin borsa endeksleri arasında bir nedensellik ilişkisinin olup olmadığı belirlenmeye çalışılmaktadır. Bu doğrultuda öncelikle çalışma kapsamına alınan verilere ilişkin bazı tanımlayıcı istatistiklere aşağıda yer verilmektedir.

Tablo 1. Petrol Fiyatı ve Ülke Endekslerine İlişkin Tanımlayıcı İstatistikler

\begin{tabular}{lcccccccc}
\hline Değişkenler & Petrol & Türkiye & $\begin{array}{c}\text { Suudi } \\
\text { A. }\end{array}$ & Urdun & BAE & Bahreyn & Katar & Kuveyt \\
\hline Ortalama & 71.91 & 62272.80 & 8101.66 & 2579.34 & 3778.55 & 1599.63 & 9060.54 & 7644.25 \\
Medyan & 68.66 & 62454.27 & 7411.47 & 2172.42 & 3848.05 & 1426.23 & 8856.63 & 6784.44 \\
Maksimum & 140.18 & 120016.00 & 19502.65 & 4829.24 & 6237.98 & 2880.79 & 13768.03 & 15442.50 \\
Minimum & 33.83 & 17081.08 & 4384.59 & 1794.59 & 1823.98 & 1048.81 & 4438.00 & 4699.08 \\
Std. Sapma & 22.32 & 24936.01 & 2542.57 & 776.44 & 1021.26 & 482.53 & 1994.93 & 2440.28 \\
Gözlem Sa- & 180.00 & 180.00 & 180.00 & 180.00 & 180.00 & 180.00 & 180.00 & 180.00 \\
y1s1 & & & & & & & & \\
\hline
\end{tabular}

Tablo 1 incelendiğinde, petrol fiyat verisine ilişkin ortalamanın 71,91 olduğu belirlenmiştir. Ülke endeksleri içerisinde ise en yüksek ortalamaya sahip olan ülke endeksinin 62272,80 ortalama ile Türkiye endeksine ait serinin olduğu bunu ise sirasıyla Katar ve Suudi Arabistan endekslerinin takip ettiği tespit edilmiştir. En düşük ortalamaya ise 1599,63 değeri ile Bahreyn endeksinin sahip olduğu görülmektedir. Ayrıca, ülke endekslerine ilişkin standart sapmaların incelenmesi neticesinde, en yüksek standart sapmaya 24936,01 ile Türkiye endeksinin sahip olduğu, Kuveyt ve Katar gibi ülkelerin ise Türkiye'yi takip ettiği görülmektedir. En düşük standart sapmanın ise 482,53 değeri ile Bahreyn endeksi için hesaplandığı belirlenmiştir. Petrol fiyatına ilişkin standart sapmanın incelenmesi neticesinde ise standart sapmanın 22,32 olarak hesaplandığ1 görülmektedir. $\mathrm{Bu}$ durum Türkiye, Suudi Arabistan ve Kuveyt gibi ülkelerin 
endekslerinde volatilitenin diğer ülkelere nazaran daha yüksek olduğunu ortaya koymaktadır. Bu sonuç maksimum ve minimum değerleri tarafından da desteklenmektedir.

Çalışmada ayrıca, petrol fiyatları ile ülke endeksleri arasındaki korelasyon düzeyleri de incelenmektedir. Bu kapsamda elde edilen sonuçlar aşağıda yer alan Tablo 2'de gösterilmektedir.

Tablo 2 incelendiğinde, özellikle Ortadoğu ülkelerinin bazıları arasındaki yüksek korelasyon düzeyleri dikkat çekmektedir. Buna göre en yüksek korelasyon düzeyinin 0.892 değeri ile Ürdün ve Bahreyn ülke endeksleri arasında tespit edildiği bunu ise Kuveyt - Bahreyn, Kuveyt - Ürdün ve Katar - BAE ülkeleri arasındaki yüksek korelasyon düzeylerinin takip ettiği görülmektedir.

Tablo 2. Petrol Fiyatı ve Ülke Endeksleri Arasındaki Korelasyon İlişkisi

\begin{tabular}{lcccccccc}
\hline Değişkenler & Petrol & Türkiye & Suudi. A & Ürdün & BAE & Bahreyn & Katar & Kuveyt \\
\hline Petrol & 1.000 & & & & & & & \\
Türkiye & -0.121 & 1.000 & & & & & & \\
Suudi A. & 0.261 & -0.164 & 1.000 & & & & & \\
Ürdün & 0.108 & -0.597 & 0.634 & 1.000 & & & & \\
BAE & -0.233 & 0.386 & 0.539 & 0.257 & 1.000 & & & \\
Bahreyn & 0.343 & -0.590 & 0.485 & 0.892 & 0.180 & 1.000 & & \\
Katar & 0.374 & 0.446 & 0.421 & 0.013 & 0.795 & -0.075 & 1.000 & \\
Kuveyt & 0.462 & -0.450 & 0.413 & 0.791 & 0.095 & 0.876 & -0.035 & 1.000 \\
\hline
\end{tabular}

Türkiye ile Ortadoğu ülkeleri arasındaki ilişki incelendiğinde ise korelasyon düzeylerinin genel olarak düşük seviyelerde olduğu ancak Türkiye'nin Bahreyn Ürdün, Kuveyt ve Katar ülkeleri ile olan korelasyon düzeyleri dikkat çekmektedir. Son olarak, bahsi geçen ülke endekslerinin petrol fiyatı ile korelasyon düzeylerinin incelenmesi neticesinde ülke endekslerinin petrol fiyatları ile genel anlamda düşük korelasyona sahip oldukları görülmektedir. Bu doğrultuda, petrol fiyatı ile en yüksek korelasyon düzeyine sahip olan endeksin 0,462 değeri Kuveyt endeksi olduğu bun ise sırasıyla Katar ve Bahreyn ülkelerinin takip ettiği görülmektedir.

Tanımlayıcı istatistiklerin ve korelasyon düzeylerinin incelenmesinin ardında çalışma kapsamında ele alınan petrol fiyatı ve ülke endekslerine ait serilerin durağanlık düzeylerinin incelenmesi için birim kök testleri gerçekleştirilmiştir. Bu kapsamda öncelikle, yapısal kırılmaları dikkate almayan ADF ve PP gibi literatürde sıklıkla kullanılan birim kök testleri 
ardından ise yapısal kırılma tarihinin içsel olarak belirlendiği Zivot Andrews, tek kırılmalı birim kök testi kullanılmış ve elde edilen sonuçlar aşağıda yer alan tablolarda verilmiştir.

Tablo 3. Augmented Dickey Fuller (ADF) Birim Kök Testi

\begin{tabular}{ccccc}
\hline \multirow{2}{*}{ Değişkenler } & \multicolumn{2}{c}{ Düzey Hali } & \multicolumn{2}{c}{ Birinci Fark } \\
\cline { 2 - 5 } & Sabit & Sabit ve Trend & Sabit & Sabit ve Trend \\
\hline Petrol & -2.538695 & -2.905283 & $-10.26775^{* * *}$ & $-10.26800^{* * *}$ \\
Türkiye & -1.527655 & -3.088182 & $-13.97753^{* * *}$ & $-13.94578^{* * *}$ \\
Suudi & -2.463806 & -2.684355 & $-10.96268^{* * *}$ & $-10.93558^{* * *}$ \\
Ürdün & -1.418775 & -3.072052 & $-10.39789^{* * *}$ & $-10.42853^{* * *}$ \\
BAE & -2.482914 & -2.085360 & $-7.674902^{* * *}$ & $-11.34693^{* * *}$ \\
Bahreyn & -1.775141 & -2.744339 & $-5.449414^{* * *}$ & $-5.439012^{* *}$ \\
Katar & -2.541250 & -2.735060 & $-12.99223^{* * *}$ & $-12.97226^{* * *}$ \\
Kuveyt & -2.159133 & -3.108186 & $-8.514795^{* * *}$ & $-8.551947^{* * *}$ \\
\hline
\end{tabular}

Uygulanan ADF birim kök testi için kritik değerler, Sabit terimli modeller için \%1, \%5 ve \%10 önem düzeyinde sırasıyla $-3.528515,-2.904198$ ve -2.589562; sabit terimli ve trendli modeller için ise $\% 1, \% 5$ ve $\% 10$ önem düzeyinde sirasiyla $-4.096614,-3.476275$ ve -3.165610 olarak verilmektedir. Ayrıca önem düzeyini belirtmek için kullanılan ${ }^{* * *},{ }^{* *}$ ve ${ }^{*}$ ifadeleri serilerin sırasıyla $\% 1, \% 5$ ve $\% 10$ önem düzeyinde durağan olduklarını göstermektedir.

Tablo 4. Philip Peron (PP) Birim Kök Testi

\begin{tabular}{ccccc}
\hline \multirow{2}{*}{ Değişkenler } & \multicolumn{2}{c}{ Düzey Hali } & \multicolumn{2}{c}{ Birinci Fark } \\
\cline { 2 - 5 } & Sabit & Sabit ve Trend & Sabit & Sabit ve Trend \\
\hline Petrol & -2.562367 & -2.820991 & $-10.31043^{* * *}$ & $-10.30253^{* * *}$ \\
Türkiye & -1.484214 & -3.076104 & $-13.98669^{* * *}$ & $-13.95523^{* * *}$ \\
Suudi & -2.504172 & -2.715579 & $-10.97205^{* * *}$ & $-10.94491^{* * *}$ \\
Ürdün & -2.038196 & -3.155962 & $-10.83469^{* * *}$ & $-10.85820^{* * *}$ \\
BAE & -2.380645 & -2.545530 & $-11.36279^{* * *}$ & $-11.33014^{* * *}$ \\
Bahreyn & -1.442339 & -2.321455 & $-8.631554^{* * *}$ & $-8.620029^{* * *}$ \\
Katar & -2.544613 & -3.133626 & $-13.02306^{* * *}$ & $-13.00291^{* * *}$ \\
Kuveyt & -1.973615 & -2.813115 & $-8.643079^{* * *}$ & $-8.626278^{* * *}$ \\
\hline
\end{tabular}

Uygulanan PP birim kök testi için kritik değerler, Sabit terimli modeller için \%1, \%5 ve \%10 önem düzeyinde sırasıyla -3.528515, -2.904198 ve 2.589562; sabit terimli ve trendli modeller için ise $\% 1, \% 5$ ve \%10 önem düzeyinde sırasıyla $-4.096614,-3.476275$ ve -3.165610 olarak verilmektedir. 
Ayrıca önem düzeyini belirtmek için kullanılan ${ }^{* * *},{ }^{* *}$ ve ${ }^{*}$ ifadeleri serilerin sırasıyla \%1, \%5 ve \%10 önem düzeyinde durağan olduklarını göstermektedir.

Petrol fiyatı ve ülke endekslerine ait serilerin durağanlığının ADF ve PP birim kök testleri yardımı ile incelenmesi sonucunda elde edilen bulgular yukarıda yer alan Tablo 3 ve 4'de verilmektedir. Buna göre petrol fiyatı ve belirlenen ülke endekslerini temsil eden seriler için hesaplanan test istatistikleri, serilerin düzey değerlerde birim kök içermediğini göstermektedir. Bu nedenle tüm serilerin birinci farkı alınmış ve test istatistikleri tekrar hesaplanmıştır. Birinci farklarının alınması neticesinde ise elde edilen test istatistiklerinin mutlak değer olarak kritik değerlerden daha büyük olarak hesaplandığı ve tüm serilerin durağan olduğu belirlenmiştir.

ADF ve PP gibi literatürde sıklıkla kullanılan ve yapısal kırılmaları dikkate almayan birim kök testlerinin gerçekleştirilmesinin ardından serilerin durağanlığının Zivot Andrews, tek kırılmalı birim kök testi yardımı ile de test edilmesinin faydalı olacağı düşünülmüş ve gerçekleştirilen test sonucunda elde edilen bulgulara aşağıda yer verilmiştir.

Tablo 5. Zivot Andrews Birim Kök Testi

\begin{tabular}{lllll}
\hline \multirow{2}{*}{ Ülkeler } & \multicolumn{2}{c}{ Sabitte Kırılma } & \multicolumn{2}{l}{ Sabitte ve Trendde Kırılma } \\
\cline { 2 - 5 } & $\begin{array}{l}\text { Test } \\
\text { İstatistiği }\end{array}$ & $\begin{array}{l}\text { Kırılma } \\
\text { Tarihi }\end{array}$ & $\begin{array}{l}\text { Test } \\
\text { İstatistiği }\end{array}$ & $\begin{array}{l}\text { Kırılma } \\
\text { Tarihi }\end{array}$ \\
\hline Petrol & $-5.362^{* * *}$ & 2014 Ağustos & $-5.195^{* * *}$ & 125 \\
\hline Türkiye & -3.939 & 2007 Kasım & $-5.678^{* * *}$ & 44 \\
\hline Suudi & $-6.946^{* * *}$ & 2006 Ocak & $-6.061^{* * *}$ & 22 \\
\hline Ürdün & $-4.650^{*}$ & 2008 Temmuz & -4.344 & 52 \\
\hline BAE & $-4.600^{*}$ & 2012 Ekim & -4.321 & 50 \\
\hline Bahreyn & $-6.046^{* * *}$ & 2008 Mayıs & $-4.869^{*}$ & 52 \\
\hline Katar & $-4.587^{* *}$ & 2013 Şubat & -4.440 & 107 \\
\hline Kuveyt & $-7.082^{* * *}$ & 2008 Eylül & -4.667 & 54 \\
\hline
\end{tabular}

Kritik değerler Zivot ve Andrews (1992)'den alınmıştır. Sabitte kırılma için kritik değerler \%1, \%5 ve \%10 önem düzeyinde sırasıyla $-5.340,-4.800$ ve -4.580 şeklindedir. Sabit ve trendde kırılma için kritik değerler ise $\% 1$, $\% 5$ ve $\% 10$ önem düzeyinde sırasıyla $-5.570,-5.080$ ve -4.820 şeklindedir. Ayrıca, ${ }^{* * *},{ }^{* *}$ ve * işaretleri sirasıyla $\% 1, \% 5$ ve $\% 10$ önem düzeylerinde yapısal kırılmanın varlığını göstermektedir. 
Petrol fiyatı ve ülke endeks serilerinde yapısal kırılmanın varlığ ZivotAndrews birim kök testi yardımıyla araştırılmış ve serilerdeki yapısal değişimleri içsel olarak belirleyen Zivot-Andrews testi sonuçları Tablo 5' de verilmiştir. Buna göre elde edilen sonuçlar petrol fiyatı serisinde yapısal kırılmanın varlı̆̆ını göstermektedir. Ayrıca, sonuçlara göre çalışmaya dahil edilen tüm ülke endekslerine ait serilerde de yapısal kırılmaların varlığ 1 tespit edilmiştir. Buna göre, elde edilen test istatistikleri mutlak değer olarak kritik değerlerden büyük olduğu için meydana gelen kırılmalar ile serilerin durağan olduğu hipotezi ret edilmektedir.

Çalışma kapsamında ülke endekslerinin uzun vadede petrol fiyatları ile eşbütünleşme ilişkisine sahip olup olmadıkları bir diğer ifade ile uzun vadede birlikte hareket edip etmedikleri incelenmektedir. Bu doğrultuda Hatemi J (2008) ve Maki (2012) olmak üzere iki farklı eşbütünleşme testi kullanılmış ve elde edilen sonuçlara aşağıda yer verilmiştir.

Tablo 6. Hatemi J Eşbütünleşme Testi

\begin{tabular}{|c|c|c|c|c|c|c|}
\hline Ülkeler & \multicolumn{2}{|c|}{ Test İstatistikleri } & Kırılma Tarihleri & $\% 1$ & $\% 5$ & $\% 10$ \\
\hline \multirow{3}{*}{ Petrol - Türkiye } & $\mathrm{ADF}^{*}$ & -5.861 & 2007Temmuz 2012 Eylül & -6.503 & -6.015 & -5.653 \\
\hline & $\mathrm{Zt}$ & -4.686 & $\begin{array}{l}2007 \text { Ağustos } \\
2012 \text { Kasım }\end{array}$ & -6.503 & -6.015 & -5.653 \\
\hline & $\mathrm{Za}$ & -41.896 & 2007Ağustos 2012 Aralık & -90.794 & -76.003 & -52.232 \\
\hline \multirow{3}{*}{ Petrol - Suudi A. } & $\mathrm{ADF}$ & -5.407 & $\begin{array}{l}2007 \text { Nisan } \\
2012 \text { Ekim }\end{array}$ & -6.503 & -6.015 & -5.653 \\
\hline & $\mathrm{Zt}$ & -4.566 & $\begin{array}{l}2007 \text { Nisan } \\
2012 \text { Haziran }\end{array}$ & -6.503 & -6.015 & -5.653 \\
\hline & $\mathrm{Za}$ & -38.863 & $\begin{array}{l}2007 \text { Nisan } \\
2012 \text { Haziran }\end{array}$ & -90.794 & -76.003 & -52.232 \\
\hline \multirow{3}{*}{ Petrol - Ürdün } & $\mathrm{ADF}$ & -4.787 & $\begin{array}{l}2007 \text { Ocak } \\
2012 \text { Eylül }\end{array}$ & -6.503 & -6.015 & -5.653 \\
\hline & $\mathrm{Zt}$ & -4.1 & $\begin{array}{l}2007 \text { Haziran } \\
2012 \text { Aralık }\end{array}$ & -6.503 & -6.015 & -5.653 \\
\hline & $\mathrm{Za}$ & -32.225 & $\begin{array}{l}2007 \text { Haziran } \\
2012 \text { Aralık }\end{array}$ & -90.794 & -76.003 & -52.232 \\
\hline
\end{tabular}




\begin{tabular}{|c|c|c|c|c|c|c|}
\hline \multirow{3}{*}{ Petrol-BAE } & $\mathrm{ADF}$ & -5.048 & $\begin{array}{l}2006 \text { Aralık } \\
2012 \text { Eylül }\end{array}$ & -6.503 & -6.015 & -5.653 \\
\hline & $\mathrm{Zt}$ & -4.434 & $\begin{array}{l}2007 \text { Ağustos } \\
2012 \text { Haziran }\end{array}$ & -6.503 & -6.015 & -5.653 \\
\hline & $\mathrm{Za}$ & -36.184 & $\begin{array}{l}2007 \text { Ağustos } \\
2012 \text { Haziran }\end{array}$ & -90.794 & -76.003 & -52.232 \\
\hline \multirow{3}{*}{ Petrol - Bahreyn } & $\mathrm{ADF}^{*}$ & -5.84 & $\begin{array}{l}2010 \text { Mart } \\
2012 \text { Nisan }\end{array}$ & -6.503 & -6.015 & -5.653 \\
\hline & $\mathrm{Zt}^{*}$ & -5.708 & $\begin{array}{l}2010 \text { Ocak } \\
2012 \text { Haziran }\end{array}$ & -6.503 & -6.015 & -5.653 \\
\hline & $\mathrm{Za}$ & -48.101 & $\begin{array}{l}2009 \text { Ağustos } \\
2012 \text { Haziran }\end{array}$ & -90.794 & -76.003 & -52.232 \\
\hline \multirow{3}{*}{ Petrol - Katar } & $\mathrm{ADF}^{*}$ & -5.74 & $\begin{array}{l}2006 \text { Eylül } \\
2012 \text { Mart }\end{array}$ & -6.503 & -6.015 & -5.653 \\
\hline & $\mathrm{Zt}$ & -4.808 & $\begin{array}{l}2006 \text { Ağustos } \\
2012 \text { Şubat }\end{array}$ & -6.503 & -6.015 & -5.653 \\
\hline & $\mathrm{Za}$ & -42.101 & $\begin{array}{l}2006 \text { Ağustos } \\
2012 \text { Şubat }\end{array}$ & -90.794 & -76.003 & -52.232 \\
\hline \multirow{3}{*}{ Petrol - Kuveyt } & $\mathrm{ADF}^{*}$ & 5.927 & $\begin{array}{l}2010 \text { Mart } \\
2012 \text { Nisan }\end{array}$ & -6.503 & -6.015 & -5.653 \\
\hline & $\mathrm{Zt}$ & 5.077 & $\begin{array}{l}2010 \text { Mayıs } \\
2012 \text { Mayıs }\end{array}$ & -6.503 & -6.015 & -5.653 \\
\hline & $\mathrm{Za}^{*}$ & -57.636 & 2010 Mayıs 2012 Mayıs & -90.794 & -76.003 & -52.232 \\
\hline
\end{tabular}

$A D F^{*}, Z^{*}$ ve Z Z $a^{*}$ test istatistiklerinin $\% 1, \% 5$ ve \%10 anlamlllk düzeyindeki kritik tablo değerleri Hatemi $J$ (2008) çalışmasından elde edilerek tabloda verilmektedir. Triminaj 0.15 alınmıştır. Ayrıca ${ }^{* * * * *}$, ve * sırasıyla \%1, \%5 ve \%10 önem düzeylerinde eşbütünleşmeyi göstermektedir.

Seriler üzerinde ilk olarak Hatemi J (2008) eşbütünleşme testi gerçekleştirilmiş ve elde edilen bulgulara Tablo 6'da yer verilmiştir. Tabloya göre, farklı dönemlere ait kırılma tarihleri tespit edilmiştir. Bu kırılma tarihleri söz konusu ülke endeksleri ile petrol fiyatı arasındaki ilişkide meydana gelen yapısal değişimleri işaret etmektedir. Elde edilen kırılma tarihlerinin incelenmesi sonucunda büyük bir kısmının 2008-2012 yılları arasındaki dönem içeresinde gerçekleştiği görülmektedir. Bu dönem içerisinde gerek küresel ekonomik krizin etkisinin gerekse arap baharının etkisinin hissedildiği ifade edilebilir. Elde edilen ADF, Zt ve Za test istatistikleri değerlendirildiğinde, Türkiye, Bahreyn, Katar ve Kuveyt gibi ülkelerin endekslerinin petrol fiyatı ile eşbütünleşik bir ilişkiye sahip oldukları görülmektedir. Diğer bir ifade ile bahsi geçen ülkelerin endeksleri uzun vadede petrol fiyatı ile birlikte hareket etmektedir. 
Tablo 7. Maki Eşbütünleşme Testi

\begin{tabular}{|c|c|c|c|c|c|}
\hline Değişken & $\mathrm{T}$ & Kırılma Tarihleri & $\% 1$ & $\% 5$ & $\% 10$ \\
\hline \multicolumn{6}{|l|}{ Model 0} \\
\hline Petrol - Türkiye & -4.20 & $\begin{array}{l}2012 \text { Nisan, } 2013 \text { Ağustos, } 2015 \text { Hazi- } \\
\text { ran, 2017 Eylül, } 2018 \text { Haziran }\end{array}$ & -6.25 & -5.63 & -5.26 \\
\hline Petrol - Suudi A. & -3.63 & $\begin{array}{c}2008 \text { Nisan, } 2010 \text { Nisan, } 2011 \text { Nisan, } \\
2017 \text { Temmuz, } 2018 \text { Haziran } \\
\end{array}$ & & & \\
\hline Petrol - Ürdün & -3.73 & $\begin{array}{l}2009 \text { Nisan, } 2010 \text { Ağustos, } 2012 \text { Nisan, } \\
2017 \text { Temmuz, } 2018 \text { Haziran } \\
\end{array}$ & & & \\
\hline Petrol - BAE & -4.47 & $\begin{array}{l}2005 \text { Haziran, } 2009 \text { Nisan, } 2011 \text { Eylül, } \\
2014 \text { Ocak, } 2014 \text { Ekim }\end{array}$ & & & \\
\hline Petrol - Bahreyn & $-5.65^{* *}$ & $\begin{array}{l}2008 \text { Mayıs, } 2009 \text { Nisan, } 2010 \text { A ğustos, } \\
2012 \text { Nisan, } 2018 \text { Haziran } \\
\end{array}$ & & & \\
\hline Petrol - Katar & -3.91 & $\begin{array}{c}2012 \text { Nisan, } 2015 \text { Haziran, } 2016 \text { Mayıs, } \\
2017 \text { Eylül, } 2018 \text { Haziran } \\
\end{array}$ & & & \\
\hline Petrol - Kuveyt & -3.48 & $\begin{array}{l}2011 \text { Eylül, } 2015 \text { Haziran, } 2016 \text { Mayıs, } \\
2017 \text { Eylül, } 2018 \text { Haziran }\end{array}$ & & & \\
\hline \multicolumn{6}{|l|}{ Model 1} \\
\hline Petrol - Türkiye & -4.08 & $\begin{array}{l}2012 \text { Nisan, } 2014 \text { Eylül, } 2015 \text { Haziran, } \\
2017 \text { Eylül, } 2018 \text { Haziran }\end{array}$ & -6.51 & -5.94 & -5.62 \\
\hline Petrol - Suudi A. & -4.10 & $\begin{array}{l}2012 \text { Nisan, } 2013 \text { Mart, } 2016 \text { Mayıs, } \\
2017 \text { Temmuz, } 2018 \text { Haziran }\end{array}$ & & & \\
\hline Petrol - Ürdün & -4.46 & $\begin{array}{c}2011 \text { Şubat, } 2012 \text { Nisan, } 2013 \text { Mart, } \\
2015 \text { Haziran, } 2017 \text { Temmuz }\end{array}$ & & & \\
\hline Petrol - BAE & -4.45 & $\begin{array}{l}2009 \text { Nisan, } 2012 \text { Nisan, } 2015 \text { Haziran, } \\
2018 \text { Nisan, } 2017 \text { Şubat }\end{array}$ & & & \\
\hline Petrol - Bahreyn & -4.84 & $\begin{array}{c}2011 \text { Eylül,106, } 2016 \text { Mayıs, } 2017 \text { Tem- } \\
\text { muz, } 2018 \text { Haziran }\end{array}$ & & & \\
\hline Petrol - Katar & -5.12 & $\begin{array}{l}2012 \text { Nisan, } 2015 \text { Haziran, } 2016 \text { Mayıs, } \\
2017 \text { Eylül, } 2018 \text { Haziran }\end{array}$ & & & \\
\hline Petrol - Kuveyt & -4.69 & $\begin{array}{l}2012 \text { Nisan, } 2015 \text { Haziran, } 2016 \text { Mayıs, } \\
2017 \text { Temmuz, } 2018 \text { Haziran }\end{array}$ & & & \\
\hline Model 2 & & & & & -6.20 \\
\hline Petrol - Türkiye & $-6.85^{* *}$ & $\begin{array}{l}2008 \text { Nisan, } 2011 \text { Eylül, } 2014 \text { Temmuz, } \\
2015 \text { Haziran, } 2018 \text { Şubat }\end{array}$ & & & \\
\hline Petrol - Suudi A. & -4.87 & $\begin{array}{l}2008 \text { Nisan, } 2014 \text { Temmuz, } 2015 \text { Hazi- } \\
\text { ran, } 2016 \text { Mayıs, } 2017 \text { Mayıs }\end{array}$ & & & \\
\hline Petrol - Ürdün & $-6.23^{*}$ & $\begin{array}{l}2007 \text { Eylül, } 2009 \text { Nisan, } 2010 \text { Nisan, } \\
2014 \text { Ekim, } 2018 \text { Şubat }\end{array}$ & & & \\
\hline Petrol - BAE & -6.06 & $\begin{array}{l}2007 \text { Haziran, } 2009 \text { Eylül, } 2010 \text { Aralık, } \\
2011 \text { Eylül, } 2014 \text { Ekim }\end{array}$ & & & \\
\hline Petrol - Bahreyn & -4.18 & $\begin{array}{l}2010 \text { Ağustos, } 2012 \text { Nisan, } 2015 \text { Hazi- } \\
\text { ran, } 2017 \text { Temmuz, } 2018 \text { Haziran }\end{array}$ & & & \\
\hline Petrol - Katar & -3.85 & $\begin{array}{l}2012 \text { Nisan, } 2013 \text { Mart, } 2016 \text { Mayıs, } \\
2017 \text { Mayıs, } 2018 \text { Mart }\end{array}$ & & & \\
\hline Petrol - Kuveyt & $-6.41^{*}$ & $\begin{array}{l}2007 \text { Eylül, } 2008 \text { Haziran, } 2009 \text { Eylül, } \\
2014 \text { Eylül, } 2016 \text { Mayıs }\end{array}$ & & & \\
\hline
\end{tabular}




\begin{tabular}{|c|c|c|c|c|c|}
\hline Model 3 & & & & & \\
\hline Petrol - Türkiye & $-7.99 * *$ & $\begin{array}{l}2006 \text { Ekim, } 2008 \text { Haziran, } 2010 \text { Nisan, } \\
2011 \text { Eylül, } 2014 \text { Eylül }\end{array}$ & -8.28 & -7.71 & -7.36 \\
\hline Petrol - Suudi A. & -6.21 & $\begin{array}{l}2007 \text { Nisan, } 2008 \text { Mayıs, } 2009 \text { Nisan, } \\
2013 \text { Ağustos, } 2015 \text { Ekim }\end{array}$ & & & \\
\hline Petrol - Ürdün & -6.25 & $\begin{array}{l}2008 \text { Ocak, } 2012 \text { Nisan, } 2013 \text { Ağustos, } \\
2014 \text { Ekim, } 2018 \text { Şubat }\end{array}$ & & & \\
\hline Petrol - BAE & $-7.89^{* *}$ & $\begin{array}{l}2006 \text { Ağustos, } 2008 \text { Nisan, } 2012 \text { Nisan, } \\
2014 \text { Haziran, } 2018 \text { Şubat }\end{array}$ & & & \\
\hline Petrol - Bahreyn & $-7.37^{*}$ & $\begin{array}{l}2007 \text { Haziran, } 2011 \text { Eylül, } 2012 \text { Tem- } \\
\text { muz, } 2014 \text { Ocak, } 2018 \text { Ocak }\end{array}$ & & & \\
\hline Petrol - Katar & -6.58 & $\begin{array}{l}2007 \text { Nisan, } 2008 \text { Eylül, } 2012 \text { Nisan, } \\
2013 \text { Mart, } 2018 \text { Şubat }\end{array}$ & & & \\
\hline Petrol - Kuveyt & $-7.39^{*}$ & $\begin{array}{l}2007 \text { Eylül, } 2011 \text { Eylül, } 2014 \text { Ağustos, } \\
2015 \text { Haziran, } 2018 \text { Mayss }\end{array}$ & & & \\
\hline
\end{tabular}

Tablo 7'de verilen test istatistikleri ile birlikte verilen, ${ }^{* * *},{ }^{* *}$ ve ${ }^{*}$ sembolleri sırasıyla \%1, \%5, \% 10 anlamlılık düzeyinde eşbütünleşme ilişkisinin varlığını ifade etmektedir.

Ülke endeklerinin petrol fiyatı ile eşbütünleşme ilişkisine sahip olup olmadığı beş kırılmaya kadar müsaade eden Maki eşbütünleşme testi ile de incelenmiştir. Buna göre Maki testi kapsamında gerçekleştirilen dört modele ilişkin kırılma tarihleri tespit edilmiştir. Ayrıca ikinci model d1şında diğer üç modelde hesaplanan test istatistikleri dikkate alındığında Türkiye, Ürdün, BAE, Bahreyn, Katar ve Kuveyt gibi ülkelere ait endekslerin petrol fiyatı ile eşbütünleşme ilişkisine sahip olduğu görülmektedir. Bir diğer ifade ile elde edilen bulgular bahsi geçen ülke endekslerinin uzun dönemde petrol fiyatı ile birlikte hareket ettiğine işaret etmektedir.

Eşbütünleşme testleri yardımı ile genel olarak ülke endekslerinin petrol fiyatları ile eşbütünleşik ilişkiye sahip olduklarının belirlenmesi sonrasında, ülke endeksleri ile petrol fiyatı arasında bir nedensellik ilişkisinin var olup olmadığı Toda Yamamoto ve Fourier Toda Yamamoto nedensellik testleri yardımı ile incelenmiş ve elde edilen bulgulara aşağıda yer verilmiştir.

Maksimum $k$ ve $p$ sırasıyla 3 ve13 olarak ayarlanmış olup ideal $k$ ve $p$ değerleri Akaike bilgi kriteri ile belirlenmektedir. p değeri ise, 1.000 defa tekrarlanan bootstrap dağılımına dayanmaktadır. 
Tablo 8. Petrol Fiyatından Ülke Endekslerine Doğru Nedensellik İlişkisi Test Sonuçları

\begin{tabular}{lcccc}
\hline \multirow{2}{*}{ Petrol => Ülke Endeksleri } & \multicolumn{2}{c}{ Toda Yamamoto } & \multicolumn{2}{c}{ Fourier Toda Yamamoto } \\
\cline { 2 - 5 } & F İstatistik & $\begin{array}{c}\text { Bootstrap p } \\
\text { Değeri }\end{array}$ & $\begin{array}{c}\text { F İstatis- } \\
\text { tik }\end{array}$ & $\begin{array}{c}\text { Bootstrap p } \\
\text { Değeri }\end{array}$ \\
\hline Petrol => Türkiye & 0.370 & 0.860 & 0.472 & 0.788 \\
Petrol => Suudi A. & 2.978 & 0.213 & 5.267 & 0.172 \\
Petrol => Ürdün & 2.113 & 0.546 & 1.764 & 0.635 \\
Petrol => BAE & 23.260 & 0.070 & 19.769 & 0.114 \\
Petrol => Bahreyn & 3.660 & 0.329 & 31.980 & 0.007 \\
Petrol => Katar & 2.188 & 0.320 & 21.935 & 0.067 \\
Petrol => Kuveyt & 20.263 & 0.000 & 25.250 & 0.000 \\
\hline
\end{tabular}

Tablo 8'de petrol fiyatlarından çalışma kapsamında ele alınan ülke endekslerine doğru bir nedensellik ilişkisinin var olup olmadığına ilişkin gerçekleştirilen nedensellik testlerinin sonuçlarına yer verilmektedir. Buna göre Toda Yamamoto nedensellik testi sonucunda elde edilen bulgular petrol fiyatlarından BAE ve Kuveyt endekslerine doğru bir nedensellik ilişkisinin var olduğunu göstermektedir. Yapısal kırılmaları dikkate alan Fourier Toda Yamamoto nedensellik testi sonucunda elde edilen bulgular ise nedensellik ilişkisinin petrol fiyatlarından Bahreyn, Katar ve Kuveyt gibi ülke endekslerine doğru olduğunu işaret etmektedir.

Maksimum $k$ ve $p$ sirasiyla 3 ve13 olarak ayarlanmış olup ideal $k$ ve $p$ değerleri Akaike bilgi kriteri ile belirlenmektedir. p değeri ise, 1.000 defa tekrarlanan bootstrap dağılımına dayanmaktadır.

Tablo 9. Ülke Endekslerinden Petrol Fiyatına Doğru Nedensellik İlişkisi Test Sonuçlari

\begin{tabular}{lcccc}
\hline \multirow{2}{*}{ Ülke Endeksleri => Petrol Fiyatı } & \multicolumn{2}{c}{ Toda Yamamoto } & \multicolumn{2}{c}{ Fourier Toda Yamamoto } \\
\cline { 2 - 5 } & F İstatistik & $\begin{array}{c}\text { Bootstrap p } \\
\text { Değeri }\end{array}$ & $\begin{array}{c}\text { F İstatis- } \\
\text { tik }\end{array}$ & $\begin{array}{c}\text { Bootstrap p } \\
\text { Değeri }\end{array}$ \\
\hline Türkiye => Petrol & 0.094 & 0.950 & 0.136 & 0.937 \\
Suudi A. => Petrol & 0.962 & 0.645 & 3.102 & 0.370 \\
Ürdün $>$ Petrol & 3.801 & 0.285 & 5.482 & 0.126 \\
BAE $=>$ Petrol & 31.327 & 0.005 & 42.320 & 0.001 \\
Bahreyn => Petrol & 5.747 & 0.129 & 14.755 & 0.336 \\
Katar $\Rightarrow$ Petrol & 0.573 & 0.741 & 8.411 & 0.810 \\
Kuveyt $\Rightarrow>$ Petrol & 5.919 & 0.070 & 9.598 & 0.023 \\
\hline
\end{tabular}

Çalışmada son olarak ülke endekslerinden petrol fiyatlarına doğru bir nedensellik ilişkisinin var olup olmadığı test edilmiştir. Bu doğrultuda 
gerçekleştirilen Toda Yamamoto ve Fourier Toda Yamamoto testleri neticesinde elde edilen bulgular BAE ve Kuveyt gibi ülke endekslerinden petrol fiyatlarına doğru da bir nedensellik ilişkisinin var olduğunu ortaya koymaktadir.

\section{Sonuç}

Sanayileşmenin her geçen gün daha da ilerlemesine istinaden petrol, modern ekonomiler için önemli bir girdi olarak gün yüzüne çımış bulunmaktadır. Gelişmiş ülke ekonomilerin enerji prodüktivitesi yüksek iken, gelişmekte olan ülke ekonomileri de enerjiye her geçen gün daha yoğun bir şekilde ihtiyaç duymaktadır. Bunun yanı sıra, gelişmekte olan ülke piyasalarında üretim süreci için önemli bir girdi olan petrolün çoğu zaman ikamesi söz konusu olmamaktadır. Bu durum bahse konu ekonomileri petrolde yaşanan fiyat değişimlerine karşı daha kırılgan ve hassas hale getirmektedir. Petrol fiyatlarında yaşanan değişiklikler sıklıkla pay senedi fiyatlarındaki dalgalanmaları dolayısıyla borsa geri dönüşlerini anlama noktasında da etkili bir faktör olarak karşımıza çıkmaktadır (Karhan ve Aydin, 2018).

Petrol fiyatı ile borsa arasındaki ilişki son zamanlarda araştırmacıların dikkatini çekmektedir. Bu kapsamda gerçekleştirilen birçok çalışma bulunmaktadır. Bu çalışma kapsamında da petrol fiyatları ile borsa endeksleri arasındaki nedensellik ilişkisi ele alınmaktadır. Çalışma da öncelikle, petrol fiyatları ile ülke endekslerinin uzun dönemde birlikte hareket edip etmediği incelenmiş ve bu hususta Hatemi J (2008) ve Maki (2012) eşbütünleşme testlerinden yararlanılmıştır. Daha sonra ise nedensellik ilişkisinin ortaya koyulmasında Toda Yamamoto yaklaşımı ve literatüre yeni kazandırılan Fourier Toda Yomamoto yaklaşımlarından faydalanılmıştır.

Bu çalışmada hedeflenen temel nokta petrol fiyatları ile Türkiye, Suudi Arabistan, Ürdün, Birleşik Arap Emirlikleri, Bahreyn, Katar ve Kuveyt gibi ülkelerin borsa endeksleri arasında nedensellik ilişkisinin var olup olmadığı hususudur. Zira bahsi geçen ülkelerden Türkiye dışındaki ülkeler Ortadoğu ülkeleridir. Bu ülkelerin ekonomileri açısından petrol üretimi hayati öneme sahiptir. Türkiye ise bir petrol ithalatçısı ülke olmanın yanı sıra önemli bir enerji koridoru durumundadır. Son yıllarda gelişen sanayisi ve ekonomisi nedeni ile enerjiye daha fazla ihtiyaç duymaktadır. Bu 
nedenle petrol fiyatlarında yaşanan şokların veya yapısal değişimlerin bu ülke endekslerinde etkili olacağı düşünülmektedir.

Bundan dolayı çalışma kapsamında Nisan 2004 ile Mart 2019 tarihleri arasındaki döneme ilişkin aylık veriler kullanılarak, petrol fiyatları ile Türkiye, Suudi Arabistan, Ürdün, Birleşik Arap Emirlikleri, Bahreyn, Katar ve Kuveyt gibi ülkelerin borsa endeksleri arasında anlamlı bir nedensellik ilişkisinin olup olmadığı test edilmiştir.

Çalışmada öncelikle, petrol fiyatları ile ülke endekslerinin uzun dönemde birlikte hareket edip etmediği incelenmiş ve bu hususta Hatemi J (2008) ve Maki (2012) eşbütünleşme testleri sonucunda elde edilen bulgular Suudi Arabistan dışındaki diğer ülkelerin endekslerinin uzun vadede petrol fiyatları ile eşbütünleşik ilişkiye sahip olduklarını ve birlikte hareket ettiklerini ortaya koymaktadır. Eşbütünleşme ilişkisinin belirlenmesinin ardından gerçekleştirilen Toda Yamamoto, Fourier Toda Yamamoto nedensellik testleri neticesinde elde edilen bulgular ise petrol fiyatlarından BAE, Bahreyn, Katar ve Kuveyt endekslerine doğru bir nedensellik ilişkisinin var olduğunu göstermektedir. Bununla birlikte nedensellik testleri BAE ve Kuveyt gibi ülke endekslerinden petrol fiyatlarına doğru da bir nedensellik ilişkisinin var olduğunu ortaya koymaktadır. Buna göre petrol fiyatlarından Bahreyn ve Katar ülkelerine ait endekslere doğru tek yönlü bir nedensellikten söz edilirken, petrol fiyatları ile BAE ve Kuveyt ülkelerine ait endeksler arasında çift yönlü bir nedensellikten bahsedilmektedir.

Çalışmanın sonucu göstermektedir ki petrol fiyatları ve borsa endeks değeri arasındaki ilişki petrol arzının fazla olduğu Ortadoğu ülkeleri için hassas bir konudur. Petrol fiyatları ve borsa endeks değeri arasındaki nedenselliğin yönünün ortaya çıkarılması petrol fiyatlarında yaşanan aşırı dalgalanmaların ülkelerin borsa endeks değeri üzerinde ne tür etkiler meydana getireceğini anlamak için önem arz etmektedir. Borsa endeks değerinin yükselmesi o ülkenin hisse senedi piyasalarına yatırımların artmasına neden olacaktır. Yabancı yatırımların finansal piyasalara pörtföy yatırımları şeklinde akması ülkelerin sermaye arzını doğrudan etkileyecek ve oluşan sermaye fazlası ülkelerin döviz kurlarında ve faiz oranlarında değişimler meydana getirecektir. Bu kapsamda ekonomi politikalarının dikkatli bir şekilde oluşturulması gerekmektedir. Bu açıdan, bu çalışmada ortaya çıkarılan sonuçlar politika uygulacıları için önemli sonuçlar 
içermektedir. Bu çalışma nedenselliğin yönü ortaya çıarıldıktan sonra uzun dönem ve kısa dönem katsayıların elde edilerek petrol fiyatlarındaki değişimlerin borsa endeks değeri üzerindeki etkisinin ortaya konması ile geliştirilebilir. Ülke farklılıkları, makro ekonomik faktörler, yatay kesit bağımlılıkları, demografik özellikler ve ülkelerin gelişmişlik düzeyleri dikkate alınarak yapılacak yeni çalışmaların literatüre katkı sağlayacağı düşünülmektedir. 


\title{
EXTENDED ABSTRACT
}

\section{Relationship Between Oil Prices And Stock Market Index Value: A Case Of Middle East Countries}

\author{
Erkan Alsu \\ Gaziantep University
}

The aim of this study is to investigate the long-term and short-term causality relationship between oil prices and stock market index values. In this context, crude oil prices with Turkey, Saudi Arabia, Jordan, United Arab Emirates, Bahrain, the data belonging to Middle Eastern countries such as Qatar and Kuwait stock exchange index is used. In this study, monthly price data for the period between April 2004 and March 2019 are discussed. Inthis study,The reason why the Middle Eastern countries were selected is that these countries produced about one third of the world's oil production. These data were analyzed with the help of Hatemi J and Maki cointegration tests and then Toda-Yamamoto and Fourier Toda Yamamoto causality tests in order to reveal the causality relationship.

The impact of oil prices on macroeconomic variables is seen as a widely discussed and researched issue in the literature. The effects of the fluctuations in oil prices on the global economy have been one of the most important topics that have been studied frequently in the academic literature since the 1970s.

When the studies carried out in this direction are examined, the changes in oil prices since 1980s have affected inflation, growth, unemployment, current account deficit and so on. There are many studies investigating its role on economic activities.

The fluctuations in oil prices, especially due to the fact that most of the energy needs of developing countries are obtained from petroleum and byproducts, have various effects on the main economic indicators of these countries.

A study by Hammoudeh, Dibooglu and Aleisa (2004) showed a two-way relationship between Saudi stock returns and changes in oil prices.Bhar and Nikolova (2010) found that global oil price returns had a significant impact on Russian stock returns and volatility.On the other hand, Huang, Masulis and Stoll (1996) found that they could not find a significant relationship between 
oil prices and stock returns and found that oil futures were not associated with US stock returns.

First, Hatemi J (2008) cointegration test was performed on the series and the findings are given in Table 6. According to the table, the breaking dates of different periods were determined. These break dates indicate structural changes in the relationship between the country's indices and the oil price. As a result of the examination of the fracture dates obtained, it is seen that most of them occurred within the period between 2008-2012. During this period, it can be stated that both the impact of the global economic crisis and the impact of the Arab spring were felt. When the resulting test statistics evaluated the ADF $\mathrm{Zt}$ and $\mathrm{Za}$ indices of countries like Turkey Bahrain Qatar and Kuwait appear to have a co-integrated relationship with the oil price. In other words, the indices of the aforementioned countries move along with the price of oil in the long run.

Whether the country's indices had a cointegration relationship with oil price was examined by Maki cointegration test, which allowed up to five fractures. Accordingly, breakage dates for four models performed within the scope of Maki test were determined. In addition, the second model outside of Turkey Considering the statistics calculated on the other three models tested, Jordan, UAE, Bahrain, Qatar and Kuwait as the indices of the country seems to have run relationship with oil prices. In other words, the findings indicate that the indices of these countries move along with the price of oil in the long run. After the determination of the fact that the country indices have a cointegrated relationship with oil prices with the help of cointegration tests, Toda Yamamoto and Fourier Toda Yamamoto causality tests were examined to see if there is a causal relationship between the country indices and oil price.

Table 8 presents the results of the causality tests conducted to determine whether there is a causality relationship from oil prices to the country indices covered by the study.According to the findings of the Toda Yamamoto causality test, there is a causality relationship from oil prices to the UAE and Kuwait indices. The findings obtained as a result of Fourier Toda Yamamoto causality test considering structural breaks point out that causality relationship is from oil prices to country indices such as Bahrain, Qatar and Kuwait.

As a result of this study, it was found that the indices of the countries other than Saudi Arabia have a cointegrated relationship with the oil prices in the long run and there is a causal relationship from the oil prices to the UAE, Bahrain, Qatar and Kuwait indices in the short run. In addition, it is determined 
that there is a causality relationship from the stock market indexes of UAE and Kuwait countries to oil prices in the short term.

\section{Kaynakça / References}

Abdioğlu, Z. ve Değirmenci, N. (2014). Petrol fiyatları ve hisse senedi fiyatları ilişkisi: Bist sektörel analiz. Kafkas Üniversitesi İktisadi ve İdari Bilimler Fakültesi Dergisi, 5(8), 1-24.

Akinlo, O. O. (2014). Oil price and stock market: Empirical evidence from Nigeria. European Journal of Sustainable Development, 3(2), 33-40.

Alagöz, M., Alacahan, N. D. ve Akarsu, Y. (2017). Petrol fiyatlarının makro ekonomi üzerindeki etkisi-ülke karşılaştırmaları ile panel veri analizi. KMÜ Sosyal ve Ekonomik Araştırmalar Dergisi, 19 (33),144-150.

Basher, S. A.ve Perry S. (2006). Oil price risk and emerging stock markets. Global Finance Journal, 17(2), 224-51.

Bhar, R, ve Biljana, N. (2010). Global oil prices, oil industry and equity returns: Russian experience. Scottish Journal of Political Economy, 57(2), 169-86.

Blanchard, O. ve Gali J. (2007). Real wage rigidities and the new keynesian model.Journal of money. Credit and Banking, 39, 35-65.

Boyer, M. M. and Didier F. (2007). Common and fundamental factors in stock returns of Canadian oil and gas companies, Energy Economics, 29(3), 428-53.

Ciftci, D. D. (2018). The twin deficits hypothesis: New evidence from giips accounting for structural shifts in causal linkages. Journal of Management and Economics Research, 16(3), 51-69.

Enders, W. ve Jones, P. (2016). Grain prices, oil prices, and multiple smooth breaks in a var. Studies in Nonlinear Dynamics E Econometrics, 20(4), 399-419.

Fang, C.R., ve Shih Y.Y. (2014). The impact of oil price shocks on the large emerging countries' stock prices: Evidence from China, India and Russia. International Review of Economics \& Finance, 29, 330-38.

Granger, C. W. (1969). Investigating causal relations by econometric models and cross-spectral methods. Journal of the Econometric Society, 37(3), 424-438.

Güler, S. ve Nalın, H. T. (2013). Petrol fiyatlarının IMKB endeksleri üzerindeki etkisi. AİB̈̈-İ̈BF Ekonomik ve Sosyal Araştırmalar Dergisi, 9(2),79-97. 
Güngör, S., Sönmez, L., Korkmaz, Ö. ve Karaca, S. S. (2016). Petrol fiyatlarındaki değişimlerin Türkiye'nin cari işlemler açığına etkileri. Maliye ve Finans Yazıları, 106, 29-48.

Hasan, S. ve Mahbobi, M. (2013). The increasing influence of oil prices on the Canadian stock market. The International Journal of Business and Finance Research, 7(3), 27-39.

Helliwell, J. F., Sturm, P., Jarrett, P. ve Salou, G. (1986). The supply side in the OECD's macroeconomic model. OECD Economic Studies, 6, 6-129.

Herrera, A. M., ve Pesavento, E. (2009). Oil price shocks, systematic monetary policy, and the "Great Moderation". Macroeconomic Dynamics, 13(1), 107-137.

Hamilton, J. D. (1983). Oil and the macroeconomy since World War II. Journal of Political Economy, 91(2), 228-248.

Hammoudeh, S., Dibooglu, S., ve Aleisa, E. (2004). Relationships among US oil prices and oil industry equity indices. International Review of Economics E Finance, 13(4), 427-453.

Hatemi-j, A. (2008). Tests for cointegration with two unknown regime shifts with an application to financial market integration. Empirical Economics, 35(3), 497-505.

Hong, S. K., Cha, M. K., Choi, Y. S., Kim, W. C., ve Kim, I. H. (2002). Msn2p/Msn4p act as a key transcriptional activator of yeast cytoplasmic thiol peroxidase II. Journal of Biological Chemistry, 277(14), 1210912117.

Huang, R. D., Masulis, R. W., ve Stoll, H. R. (1996). Energy shocks and financial markets. Journal of Futures Markets: Futures, Options, and Other Derivative Products, 16(1), 1-27.

Jones, C. M., ve Kaul, G. (1996). Oil and the stock markets. The journal of Finance, 51(2), 463-491.

Kapusuzoğlu, A. (2011). Relationships between Oil Price and Stock Market: An Empirical Analysis from Istanbul Stock Exchange (ISE). International Journal of Economics and Finance, 3(6), 99-106.

Karhan, G. ve Aydın, H.İ. (2018). Petrol fiyatları, kur ve hisse senedi getirileri üzerine bir araştırma. Akademik Araştırmalar ve Çalışmalar Dergisi, 10(19), 405-413.

Kaul, G., veSeyhun, H. N. (1990). Relative price variability, real shocks, and the stock market. The Journal of Finance, 45(2), 479-496. 
Kilian, L., ve Park, C. (2009). The impact of oil price shocks on the US stock market. International Economic Review, 50(4), 1267-1287.

Maki, D. (2012). Tests for cointegration allowing for an unknown number of breaks. Economic Modelling, 29(5), 2011-2015.

Mercan, M., ve Yurttançıkmaz, Z. Ç. (2013). Doğrudan yabancı yatırımlar-cari işlemler açı̆̆ı ilişkisi: Türkiye için ampirik bir analiz. Bankacılar Dergisi, 87, 57-78.

Miller, J. Isaac, ve Ronald A. Ratti. (2009). Crude oil and stock markets: stability, instability, and bubbles. Energy Economics, 31(4), 559-68.

Nazlioglu, S., Gormus, N. A.ve Soytas, U. (2016). Oil prices and real estate investment trusts (REITs): Gradual-shift causality and volatility transmission analysis. Energy Economics, 60, 168-175.

O'Neil, D. A., Margaret M. H., ve Diana B. (2008). Women's careers at the start of the 21st century: Patterns and Paradoxes. Journal of Business Ethics, 80(4), 727-43.

Papapetrou, E. (2001). Oil price shocks, stock market, economic activity and employment in Greece. Energy Economics, 23(5), 511-32.

Park, J. ve Ratti,R.A. (2008). Oil price shocks and stock markets in the U.S. and 13 European countries. Energy Economics, 30(5), 2587-2608.

Sadorsky, P. (1999). Oil price shocks and stock market activity. Energy Economics, 21(5), 449-69.

Sadorsky, P. (2001). Risk factors in stock returns of Canadian oil and gas companies. Energy Economics, 23(1), 17-28.

Sevüktekin, M. ve Çınar, M. (2014). Ekonometrik Zaman Serileri Analizi. Dora Yayıncilık. 4. Baskı. Bursa.

Toda, H. Y. ve Yamamoto. T. (1995). Statistical inference in vector autoregressions with possibly integrated processes. Journal of Econometrics. 66(12), 225-50.

Ventosa-Santaulària, D. ve Vera-Valdés, J. E. (2008). Granger-causality in the presence of structural breaks. Economics Bulletin, 3(61), 1-14.

Wei, Y. ve Xiaoying G. (2017). Oil price shocks and China's stock market. Energy, 140, 185-97.

Zivot, E. ve Andrews, W. K. D. (1992). Further evidence on the great crash, the oilprice shock, and the unit-root hypothesis. Journal of Business\&Economic Statistics, 10(3), 251-270. 


\section{Kaynakça Bilgisi / Citation Information}

Alsu, E. (2019). Petrol fiyatları ve borsa endeks değeri arasındaki ilişki : Ortadoğu ülkeleri örneği. OPUS-Uluslararası Toplum Araştırmaları Dergisi, 13(19), 1620-1649. DOI: 10.26466/opus.598831 